\title{
REPORT OF THE BUSINESS MEETING, FRIDAY 20 JUNE 1997
}

\section{JOHANNES VAN DER PLICHT and WILLEM G. MOOK}

Centre for Isotope Research, Nijenborgh 4, 9747 AG Groningen, the Netherlands

\section{Calibration}

The last scientific presentation at the conference was a special paper by Minze Stuiver, reviewing all radiocarbon calibration data available to date.

The first calibration data set to become widely used was published following the 12 th ${ }^{14} \mathrm{C}$ Conference in Trondheim (Stuiver and $\mathrm{Kra}$ 1986). This first calibration issue included a curve recommended by the conference (Stuiver and Pearson 1986; Pearson and Stuiver 1986). At the 14th ${ }^{14} \mathrm{C}$ Conference in Tucson, it was decided that a new calibration issue should be produced (Stuiver, Long and $\mathrm{Kra}$ 1993) in order to incorporate the wealth of new data that had become available. The initial data used to construct the 1986 curve (Stuiver 1993) were corrected slightly, but no new recommendation was made. This spawned discussions concerning which calibration curve should really be used (e.g., Scott, Harkness and Jull 1995).

Recently, all data were carefully reviewed by a working group, meeting in Heidelberg (Kromer et al. 1996) and at the present conference. In addition, revisions were made concerning the older part of the tree-ring data set. First, various corrections were made to the German dendrochronology (Spurk et al. 1998). Second, the floating pine chronology was revised (Kromer and Spurk, in press). Apart from the tree-ring data set, considerable progress has been made on corals dated by both ${ }^{14} \mathrm{C}$ and $\mathrm{U}$ series, yielding a marine calibration curve for the Late Glacial.

All new information justifies a new calibration volume of Radiocarbon (the third), to be published shortly after the proceedings of the Groningen ${ }^{14} \mathrm{C}$ Conference. Guest editors will be Minze Stuiver and Hans van der Plicht. The new integrated curve recommended for use will be known as INTCAL98. The data will be available on a World Wide Web site; the existing calibration programs will be upgraded to include the new curve.

\section{WigGLe MATChiNG}

Several computer programs for ${ }^{14} \mathrm{C}$ calibration offer wiggle matching of floating series. The uncertainty in such matches can be calculated in different ways to give different ranges. Therefore, there is a need to develop a consensus on the best procedures for wiggle matching, taking into account possible uncertainties, so that these can be implemented by different computer programs. An effort will be launched and coordinated by Christopher Bronk Ramsey.

\section{HoT SAMPLES}

The issue of "hot samples", i.e., ${ }^{14} \mathrm{C}$-enriched materials used for tracer experiments on board research ships, was raised by Pieter Grootes, with a plea for a warning to be published in specific journals. After some discussion, it was concluded that really clean working conditions are in fact the only solution to this problem. 


\section{INTERCOMPARISON}

A proposal was made by Marian Scott, Doug Harkness and Gordon Cook (Scott, Harkness and Cook 1997) to organize a further international intercomparison beginning in 1998. The comparison would consist of two experimental parts and would take place over an 18-month period. One part is designed specifically for radiometric laboratories and the other for AMS laboratories, but they would be linked through several key samples. Sample materials would include wood, peat and carbonate. It is intended that the samples will be ready for distribution by the summer of 1998 .

The organizers are currently seeking funding to ensure that there is no cost, other than sample measurement, to participating laboratories. Although the design of the study is not yet finalized, it is envisaged that each laboratory's commitment will be no more than 10-15 analyses. Each laboratory will receive a letter of invitation to participate. Further details can be obtained from Marian Scott (marian@stats.gla.ac.uk).

\section{OTHER CONFERENCES}

- Following earlier conferences in Groningen in 1981 and 1987 , the third symposium on ${ }^{14} \mathrm{C}$ and Archaeology will be held in Lyon, France, in April 1998. Chief organizer is Jacques Evin, who presented the program during the business meeting. The symposium will be bilingual (French/ English) with simultaneous translation.

- For the 17 th International ${ }^{14} \mathrm{C}$ Conference, only one proposition/offer was made: Jerusalem in $2000 \mathrm{AD}$. No questions or objections were raised after the presentation by Israel Carmi, so no vote was required and the offer was accepted.

\section{REFERENCES}

Kromer, B., Ambers, J., Baillie, M. G. L., Damon, P. E., Hesshaimer, V., Hofmann, J., Jöris, O., Levin, I., Manning, S. W., McCormac, F. G., van der Plicht, J., Spurk, M., Stuiver, M. and Weninger, B. 1996 Report: Summary of the workshop "Aspects of High-Precision Radiocarbon Calibration". Radiocarbon 38(3): 607-610.

Kromer, B. and Spurk, M., in press, Revision and extension of the tree-ring based ${ }^{14} \mathrm{C}$ calibration $9200-11900$ cal BP. In Stuiver, M., ed., Calibration issue. Radiocarbon.

Pearson, G. W. and Stuiver, M. 1986 High-precision calibration of the radiocarbon time scale, 500-2500 BC. In Stuiver, M. and Kra, R., eds., Calibration Issue. $R a$ diocarbon 28(2B): 839-862.

Scott, E. M., Harkness, D. D. and Jull, A. J. T. 1995 Report of the business meeting, Friday, 19 August 1994. In Cook, G. T., Harkness, D. D., Miller, B. F. and Scott, E. M., eds., Proceedings of the 15th International ${ }^{14} \mathrm{C}$ Conference. Radiocarbon 37(2): 826-828.

Scott, E. M., Harkness, D. D. and Cook, G. T. 1997 An- alytical Protocol and quality assurance for ${ }^{14} \mathrm{C}$ analyses: Proposal for a further intercomparison. Radiocarbon 39(3): 347-350.

Spurk, M., Friedrich, M., Hofmann, J., Remmele, S., Leuschner, H. H., Frenzel, B. and Kromer, B. 1998 Revision and extension of the German oak and pine chronologies: New evidence for the timing of the Younger Dryas/Preboreal transition. In Stuiver, M., ed., Calibration issue. Radiocarbon, in press.

Stuiver, M. 1993 A note on single-year calibration of the radiocarbon time scale, AD 1510-1954. In Stuiver, M., Long, A. and Kra, R. S., eds. Calibration 1993. Radiocarbon 35(1): 67-72.

Stuiver, M. and Kra, R., eds. 1986 Calibration Issue. $R a$ diocarbon 28(2B): 805-1030.

Stuiver, M., Long, A. and Kra, R. S., eds. 1993 Calibration 1993. Radiocarbon 35(1): 1-244.

Stuiver, M. and Pearson. G. W. 1986 High-precision calibration of the radiocarbon time scale, AD 1950-500 BC. In Stuiver, M. and Kra, R., eds., Calibration Issue. Radiocarbon 28(2B): 805-838. 